\title{
FINANCIAL TECHNOLOGY FOR SMES CAPITAL PROBLEMS WITH CROWDFUNDING METHOD
}

\author{
Mappa Panglima Banding \\ Departmen of Accounting, Faculty of Economics, Universitas Borneo Tarakan, Indonesia \\ Email: mpbanding@gmail.com
}

\begin{abstract}
Ashar
Departmen of Management, Faculty of Economics, Universitas Borneo Tarakan, Indonesia Email: ashar15401010044@gmail.com
\end{abstract}

\begin{abstract}
Ahmad Juliana
Departmen of Management, Faculty of Economics, Universitas Borneo Tarakan, Indonesia Email: ahmadjuliana75@gmail.com

Muh. Irfandy Azis

Departmen of Accounting, Faculty of Economics, Universitas Borneo Tarakan, Indonesia Email:muh.irfandyazis@gmail.com

Yohanna Thresia Nainggolan

Departmen of Accounting, Faculty of Economics, Universitas Borneo Tarakan, Indonesia Email: yohanna.thresia@gmail.com
\end{abstract}

Received: May 2020; Accepted: June 2020; Available online: July 2020

\begin{abstract}
This study motivated by Micro, Small, and Medium Enterprises (SMEs) problem. SMEs still have difficulty accessing financial institutions. This problem should overcome when SMEs utilize information technology in business management such as crowdfunding features through Financial technology, where crowdfunding has known as a funding offering facility for social interests. The study is a qualitative descriptive analysis. This study intended to decide how to use crowdfunding-based financial technology by SME's at Tarakan City. The experiment subject is a randomized participant of 15 participants based on a predetermined category faced with stakeholders SME's at Tarakan City. The data consisted of primary data non-metric or qualitative data. Participants were interviewed and examined to learn about the use of crowdfunding-based financial technology by small and medium-sized companies in Tarakan City, followed by triangulation with three models, i.e. data triangulation, investigator triangulation, and methods triangulation. Then analyzed with an interactive model through data reduction, data display, and conclusion drawing procedures. The result of the research shows that from the 15 informants in this study, there were only two informants who knew about Financial technology, and only a small proportion of SMEs at Tarakan City able to utilize Financial technology based on crowdfunding for their funding needs and use crowdfunding for working capital.
\end{abstract}

Keywords: Financial technology; Crowdfunding; Working Capital; SME’s.

\begin{abstract}
Abstrak
Penelitian ini dilatarbelakangi permasalahan pada Usaha Mikro, Kecil dan Menengah (UMKM). Dimana UMKM masih mengalami kesulitan dalam mengakses lembaga keuangan. Permasalahan ini harus diatasi ketika UMKM menggunakan teknologi informasi dalam manajemen bisnis seperti fitur crowdfunding melalui financial technology, dimana crowdfunding dikenal sebagai fasilitas penawaran pendanaan untuk kepentingan sosial. Jenis penelitian ini adalah penelitian deskriptif kualitatif. Penelitian ini bertujuan untuk mengetahui bagaimana pemanfaatan fintech berbasis crowdfunding oleh UMKM di Kota Tarakan. Informan merupakan partisipan acak sebanyak 15 partisipan berdasarkan kategori yang telah ditentukan sebelumnya yaitu pelaku UMKM di Kota Tarakan. Data yang digunakan berupa data primer Non-Metrik atau data kualitatif. Partisipan diwawancara dan
\end{abstract}


diobservasi untuk mengetahui pemanfaatan fintech berbasis crowdfunding oleh UMKM di Kota Tarakan kemudian dilakukan triangulasi dengan tiga model yaitu triangulasi data, triangulasi peneliti, dan triangulasi metode. Kemudian dianalisis dengan model interaktif melalui prosedur reduksi data, penyajian data dan verifikasi. Hasil penelitian menunjukkan bahwa dari jumlah 15 informan yang di teliti hanya ada dua informan yang mengetahui tentang fintech, dan diantara yang lainnya tidak mengerti tentang fintech, dan hanya sejumlah kecil pelaku UMKM di Kota Tarakan yang mampu memanfaatkan fintech berbasis crowdfunding untuk keperluan pendanaan dan memanfaatkan crowdfunding untuk modal kerja.

Kata Kunci : Fintech; Crowdfunding; Permodalan; UMKM.

How to Cite: Banding, M. P., Ashar, Juliana, A., Aziz, M. I., \& Nainggolan, Y. T. (2020). Financial Technology For SMEs Capital Problems With Crowdfunding Method. Media Ekonomi dan Manajemen, 35(2), 150-163. doi: http://dx.doi.org/10.24856/mem.v35i2.1503.

\section{INTRODUCTION}

Micro, small and medium-sized enterprises (SMEs) play a key role in economic development and growth, not only in developing countries such as Indonesia, but also in developed countries (Nisaputra, 2016). In Indonesia, part of MSME, In addition to playing a role in development and economic growth, it has also made a significant contribution to the resolution of unemployment and to making it a source of growth in employment and income opportunities and to the absorption of a great deal of labour (Hidayat, 2016). The number of SMEs continues to increase each year based on Data from the Bureau for Central Statistics (BPS) contribution to Gross Domestic Product (GDP), reaching $60.34 \%$ in terms of labor absorption capable of absorbing 57.9 million in various regions in Indonesia (Ardan Adhi, 2016).

SMEs have strategic opportunities to develop in Tarakan City, North Kalimantan Province. The position of the North Kalimantan region, which borders directly with the Malaysian neighbor country, as a result of the implementation of free trade within the ASEAN Economic Community (AEC) since 2015, small and medium-sized enterprises must improve their competitiveness even more. It is essential to formulate the business development strategy for SMEs. It can become recommendations for the government and other stakeholders in making a policy of empowering MSMEs in the City of Tarakan. But until now, there is still homework that although completed to improve the MSME, which is a problem faced by Disperindag related to marketing and packaging (Suwarsono, 2017).

In the field of technology, literacy, micro, small and medium-sized enterprises (SMEs) are now being promoted. Almost all developing countries and developed countries have started 4.0 in the industrial era. According to Soetrisno Bachir, the industrial age 4.0 demanded that SMEs must understand and master digitalization in various industrial sectors. Because the digitization of small and medium-sized businesses will work effectively and efficiently, as well as good quality goods and competitive prices (Bachir, 2019). Also, the use of information technology at this time is essential for SMEs because the public tends to access information via the internet. With current technological developments, not only the local market but also the international market can be located. Not only that, but SMEs also need innovation and creativity to manage their business so that consumers can see the products to be produced to reach a broader market, according to the Deputy for Financing of the Ministry of Cooperatives and SMEs (Sembiring, 2013).

Financial technology develops in 2016 as an advancement in financial services that expect to create a more 
effective and safe system for financial transactions, including payment, borrowing, transfer, or acquisition and selling of securities (Carney, 2016). Opportunities for collaboration between financial technology and the financial services sector, including savings and loan cooperatives and government institutions or organizations engaged in financing, are increasingly wide open, the impact of which can be achieved efficiency in operations, cheaper interest, especially the borrowers of business actors (Setyo, 2019).

Financial technology has four BI ratings, namely Crowdfunding and Peer to Peer (P2P) Loan, Market Aggregator, Risk and Investment Management and Transaction, Settlement and Clearance. Crowdfunding is a fundraising strategy for ventures or business units that include the wider community. The idea of crowdfunding was first introduced in the United States in 2003 with the launch of the Artisthare platform. On the website, artists are trying to raise money from their fans to produce work. It prompted the rise of other crowdfunding sites, such as Kickstarter, which supported the creative industries in 2009 and Gofundme, which helped to support various events and companies in 2010 (Freedman \& Nutting, 2015).

The term crowdfunding is asking for help from the crowd (crowd) to make funding or donate some money for specific needs, can be in return (rewards), or without certain rewards. Crowdfunding usually takes place online. Crowdfunding in Indonesia is not yet well-known and relatively new; in general, crowdfunding sites offer funding for relief in natural disasters, startup funding, film funding, infrastructure projects, and others. In this crowdfunding, creditors can come from more than one party as well as debtors, which can be in the form of institutions or individuals. It can also be done Peer to Peer (P2P) Lending or a person, or an institution can provide loans to one individual or institution (Kurniawan, 2015).

Crowdfunding acts as a mediator who brings the two parties together. Crowdfunding also allows lenders to be assessed first using data from social media and other digital-based information. The creditors can come from more than one party, as well as the debts, which can be in the form of institutions or individuals (Kurniawan, 2015). Crowdfunding itself is operated by a corporation that adheres to the Web network or to what we know as a website. Kickstarter.com and indiegogo. com are the world-famous crowdfunding websites (Irwanto, 2013). In Indonesia, the crowdfunding platform, which holds licenses from the Indonesian Financial Services Authority (OJK) until 1 May 2019, is registered and licensed to as many as 113 companies (Otoritas Jasa Keuangan, 2019).

Survey results show that the number of funds raised by crowdfunding globally in 2013 reached $\$ 6.1$ and then increased by $\$ 16.2$ billion in 2014 (Massolution, 2015). Research on crowdfunding platforms in Indonesia shows that funds raised from financial services reach $\mathrm{Rp} 0.5$ trillion (Arifin \& Wisudanto, 2017). Indeed, this importance is small compared to other traditional sources of finance, such as banking and capital markets. The crowdfunding characteristic that distinguishes it from other funding sources is that there is social capital or business capital, which is a social link that makes a person able to take action to achieve the desired goal (Prihantono, 2016).

The role of SMEs is quite vital in the development and economic growth, especially SMEs in the City of Tarakan, which have quite a strategic potential. However, SMEs still have difficulty accessing financial institutions. This problem should overcome when SMEs utilize information technology in business management such as crowdfunding features through Financial technology, 
where crowdfunding has known as a funding offering facility for social interests. In contrast, with social capital, crowdfunding can be a mediator between creditors and debtors. Understand "how to use Financial technology-based crowdfunding by SMEs in Tarakan City."

\section{LITERATURE REVIEW}

The development of Financial Technology (Financial technology) has now become the latest study in Indonesia. Financial technology's presence in Indonesia has the objective of enabling people who do not yet have financial access to banking to be touched by the presence of Financial technology. At present, there is no standard definition of Financial technology. Today, the National Digital Research Center (NDRC) describes financial technology as one of the terms used to refer to financial services innovation or economic change in conjunction with modern technology. It could also be in the sense of a startup business that helps and accelerates aspects of financial services. One type of Financial technology that often utilizes the convenience and benefits of discounted prices provided by Gopay, OVO, T-Cash, and the likes (Herdiawan, 2018)
Crowdfunding is a tool for linking entrepreneurs who want to increase capital and new investors who have financial resources and want to invest in small amounts through internet-based intermediary organizations (Valanpienơa \& Jegelevipinjtob, 2014). According to Vulkan et al. (2016) Financial technology's presence in Indonesia has the objective of enabling people who do not yet have financial access to banking to be touched by the presence of Financial technology.

Three main parties become stakeholders, namely entrepreneurs, crowdfunding platforms, and investors (backers). The main stakeholders have their respective roles and interests to play. The first stream begins with entrepreneurs (businesses or start-ups) proposing ideas, applying for funding through crowdfunding platforms, and then promising returns to investors. Supporters (investors) see the investment opportunities presented by entrepreneurs and then make a commitment to support or provide advice. The crowdfunding network serves as an intermediary that brings together investors and supporters (Valanpienora \& Jegelevipinjtơ, 2014).

Previous research related to the study to be investigated, namely the use of crowdfunding-based Financial technology by SMEs presented in the Table 1 .

Tabel 1. Empirical Review

\begin{tabular}{|c|c|c|c|c|}
\hline No & Researcher & Title & Form & Result \\
\hline 1. & $\begin{array}{l}\text { (Wandi Adiansah, } \\
\text { Nandang } \\
\text { Mulyana, dan } \\
\text { Muhammad } \\
\text { Fedryansyah, } \\
\text { 2016) }\end{array}$ & $\begin{array}{l}\text { Potensi } \\
\text { Crowdfunding Di } \\
\text { Indonesia Dalam } \\
\text { Praktik Pekerjaan } \\
\text { Social }\end{array}$ & $\begin{array}{l}\text { Jurnal Ekonomi } \\
\text { Universitas } \\
\text { Padjadjaran } \\
\text { Vol. } 3 \text { No. } 2 \\
\text { (2016) }\end{array}$ & $\begin{array}{l}\text { Social work in one of its objectives is to } \\
\text { connect clients with the needed source } \\
\text { system, or better known as social workers } \\
\text { as brokers, to conduct this crowdfunding } \\
\text { practice to connect clients who need } \\
\text { funding. }\end{array}$ \\
\hline
\end{tabular}




\begin{tabular}{|c|c|c|c|c|}
\hline No & Researcher & Title & Form & Result \\
\hline 2. & $\begin{array}{l}\text { (Budi Wibowo, } \\
\text { 2016) }\end{array}$ & $\begin{array}{l}\text { Analisa Regulasi } \\
\text { Financial } \\
\text { technology Dalam } \\
\text { Membangun } \\
\text { Perekonomian Di } \\
\text { Indonesia }\end{array}$ & $\begin{array}{l}\text { Jurnal Magister } \\
\text { Teknik Elektro } \\
\text { Universitas } \\
\text { Mercu Buana }\end{array}$ & $\begin{array}{l}\text { The existence of financial services based } \\
\text { on technology (Financial Technology) in } \\
\text { Indonesia has become a requirement in } \\
\text { line with the growth of information and } \\
\text { communication technology. In line with } \\
\text { the concept of the Indonesian Financial } \\
\text { Services Sector Master Plan (MPSJKI), } \\
\text { Financial technology can synergize with } \\
\text { the existing financial industry to provide } \\
\text { multiple benefits to the community. } \\
\text { Regulators need to develop strategic } \\
\text { policies that ensure that Financial } \\
\text { technology risks can be mitigated and } \\
\text { provide protection to the community. }\end{array}$ \\
\hline 3. & $\begin{array}{l}\text { (Salahuddin Rijal } \\
\text { Arifin dan } \\
\text { Wisudanto, 2017) }\end{array}$ & $\begin{array}{l}\text { Crowdfunding } \\
\text { Sebagai Alternatif } \\
\text { Pembiayaan } \\
\text { Pembangunan } \\
\text { Infrastruktur }\end{array}$ & $\begin{array}{l}\text { Jurnal Ekonomi } \\
\text { Universitas } \\
\text { Airlangga Vol. } \\
2 \text { (2017) }\end{array}$ & $\begin{array}{l}\text { Crowdfunding can be used as an } \\
\text { alternative to financing infrastructure } \\
\text { development, especially if the government } \\
\text { and the community have high social } \\
\text { closeness. The success of raising funds for } \\
\text { infrastructure development through } \\
\text { crowdfunding by the government will } \\
\text { influence by the social capitalformed. }\end{array}$ \\
\hline 4. & $\begin{array}{l}\text { (Muhammad } \\
\text { Mufli, 2017) }\end{array}$ & $\begin{array}{l}\text { Tanimadani.com: } \\
\text { Rancangan } \\
\text { Bangunan Model } \\
\text { Bisnis Islamic } \\
\text { Financial } \\
\text { Berbasis } \\
\text { Crowdfunding } \\
\text { Pembiayaan } \\
\text { Usaha Mikro } \\
\text { Sektor Pertanian }\end{array}$ & $\begin{array}{l}\text { Jurnal } \\
\text { Perbankan } \\
\text { Syariah Fakultas } \\
\text { Ilmu } \\
\text { Administrasi } \\
\text { Universitas } \\
\text { Brawijaya Vol. } \\
3 \text { No. 1 Tahun } \\
2017\end{array}$ & $\begin{array}{l}\text { Tanimadani.com is an Islamic financial } \\
\text { technology innovation that optimizes the } \\
\text { development of Islamic financial products } \\
\text { through the use of technology and } \\
\text { information. Tanimadani.com developed } \\
\text { in the form of crowdfunding platforms for } \\
\text { micro-business financing in the } \\
\text { agricultural sector. The application of } \\
\text { Islamic financial system principles in } \\
\text { tanimadani.com services is a distinct } \\
\text { advantage and differentiates it from } \\
\text { existing financial technology. Tanimadani. } \\
\text { com expected to increase sharia financial } \\
\text { literacy to rural farmers. }\end{array}$ \\
\hline 5. & $\begin{array}{l}\text { (Fauwaz Ahmad } \\
\text { Raihan, Demas } \\
\text { Naufal Hakim, } \\
\text { dan Muhammad } \\
\text { Rafly Nugraha, } \\
\text { 2018) }\end{array}$ & $\begin{array}{l}\text { UMKMBisa.com: } \\
\text { Solusi } \\
\text { Pembiayaan } \\
\text { Permodalan Bagi } \\
\text { UMKM Berbasis } \\
\text { Crowdfunding } \\
\text { Shariah }\end{array}$ & $\begin{array}{l}\text { Karya Tulis } \\
\text { Ekonomi Islam } \\
\text { Universitas } \\
\text { Brawijaya }\end{array}$ & $\begin{array}{l}\text { UMKMBisa.com is here to answer the } \\
\text { problem for SMEs to be able to develop } \\
\text { their business to encourage the } \\
\text { environment of the surrounding } \\
\text { environment. Sharia-based UMKMBisa. } \\
\text { com tries to facilitate MSMEs with Crowd } \\
\text { Funder with mudarabah or profit-sharing } \\
\text { systems. }\end{array}$ \\
\hline 6. & $\begin{array}{l}\text { (Dewi Maulina } \\
\text { Nurasri, 2018) }\end{array}$ & $\begin{array}{l}\text { Analisis Pengaruh } \\
\text { Venture Quality } \\
\text { dan Tingkat } \\
\text { Ketidakpastian } \\
\text { Terhadap } \\
\text { Kesuksesan } \\
\text { Pendanaan } \\
\text { UMKM Pada } \\
\text { Platform } \\
\text { Crowdfunding }\end{array}$ & $\begin{array}{l}\text { Jurnal Fakultas } \\
\text { Ekonomika dan } \\
\text { Bisnis } \\
\text { Universitas } \\
\text { Diponegoro }\end{array}$ & $\begin{array}{l}\text { This business experience, other party } \\
\text { alliances, financial projections, and loan } \\
\text { collateral have a positive impact on the } \\
\text { success of crowdfunding equity financing. } \\
\text { Meanwhile, the debt to date has no impact } \\
\text { on the success of crowdfunding equity } \\
\text { financing. Based on these results, success } \\
\text { in securing crowdfunding funding in } \\
\text { Indonesia depends on business experience, } \\
\text { other party alliances, financial projections, } \\
\text { and loan collateral. }\end{array}$ \\
\hline
\end{tabular}




\begin{tabular}{|c|c|c|c|c|}
\hline No & Researcher & Title & Form & Result \\
\hline 7. & $\begin{array}{l}\text { (Auditia } \\
\text { Setabudi, } \\
\text { Trianggoro } \\
\text { Wiradinata, 2018) }\end{array}$ & $\begin{array}{l}\text { Intense UKM } \\
\text { Dalam Adopsi } \\
\text { Financial } \\
\text { Technology Di } \\
\text { Jawa Timur }\end{array}$ & $\begin{array}{l}\text { Jurnal } \\
\text { Manajemen } \\
\text { Bisnis } \\
\text { Internasional, } \\
\text { Sekolah } \\
\text { Kewirausahaan } \\
\text { dan Humaniora } \\
\text { Universitas } \\
\text { Ciputra e-ISSN } \\
\text { No. 2622-7436 }\end{array}$ & $\begin{array}{l}\text { It can be seen from the results of the study } \\
\text { that the goals of the Indonesian people (in } \\
\text { East Java in particular) on financial } \\
\text { technology are quite high. From the side } \\
\text { of SMEs or merchants and the customer, } \\
\text { the side gets a lot of benefits. The } \\
\text { sustainability and development of this } \\
\text { product supporting by the company's } \\
\text { resources and competencies that are } \\
\text { demonstrated. The environmental aspects } \\
\text { also affect the existence of developing } \\
\text { Financial technology products. The } \\
\text { presence of competitors and partners } \\
\text { allows customers to choose according to } \\
\text { their needs. }\end{array}$ \\
\hline 8. & $\begin{array}{l}\text { (Irma Muzdalifa, } \\
\text { Inayah Aulia } \\
\text { Rahma, Bella } \\
\text { Gita Novalia, } \\
\text { 2018) }\end{array}$ & $\begin{array}{l}\text { Peran Financial } \\
\text { technology Dalam } \\
\text { Meningkatkan } \\
\text { Keuangan } \\
\text { Inklusif Pada } \\
\text { UMKM Di } \\
\text { Indonesia } \\
\text { (Pendekatan } \\
\text { Keuangan } \\
\text { Syariah) }\end{array}$ & $\begin{array}{l}\text { Jurnal Ekonomi } \\
\text { dan Perbankan } \\
\text { Syariah } \\
\text { Universitas } \\
\text { Muhammadiyah } \\
\text { Surabaya Vol. } 3 \\
\text { No. 1, } 2018\end{array}$ & $\begin{array}{l}\text { The presence of several Financial } \\
\text { technology companies also contributed to } \\
\text { the development of MSMEs. Not only has } \\
\text { financial support been limited to the } \\
\text { financing of venture capital, but the role of } \\
\text { financial technology has also been } \\
\text { extended to various aspects, such as digital } \\
\text { payment services and financial constraints } \\
\text { on the implementation of financial } \\
\text { technology in order to increase the } \\
\text { financial inclusion of small and medium- } \\
\text { sized enterprises in Indonesia } \\
\text { 1. Infrastructure } \\
\text { 2. Human Resources } \\
\text { 3. Legislation } \\
\text { 4. Lack of financial education }\end{array}$ \\
\hline 9. & $\begin{array}{l}\text { (Nurul } \\
\text { Widyaningsih, } \\
\text { 2018) }\end{array}$ & $\begin{array}{l}\text { Analysis Mitigasi } \\
\text { Resiko Financial } \\
\text { Technology Peer } \\
\text { To Peer Lending } \\
\text { Dalam } \\
\text { Penyaluran Kredit } \\
\text { Terhadap UMKM } \\
\text { Di Indonesia } \\
\text { (Studi Kasus Pada } \\
\text { PT. Amartha } \\
\text { Mikro Fintek) }\end{array}$ & $\begin{array}{l}\text { Jurnal Ilmiah } \\
\text { Universitas } \\
\text { Brawijaya }\end{array}$ & $\begin{array}{l}\text { The study found that the process of } \\
\text { Amartha's lending procedures was not } \\
\text { completely online, but still sponsored by } \\
\text { field officers. Also, the steps taken to } \\
\text { minimize the risks that occur are by } \\
\text { forming a lending group with a joint } \\
\text { responsibility system and supervision and } \\
\text { assistance by field officers every week. } \\
\text { Village tour and jamkrindo insurance } \\
\text { programs are carried out to ensure credit } \\
\text { security for investors. }\end{array}$ \\
\hline
\end{tabular}

\section{RESEARCH METHODS}

\section{Data Sources}

In this research to achieve research objectives, researchers need to determine precisely the type of data or information required because it can help researchers create questions with appropriate response categories. Useful for survey designers to think of problems as information gatherers from the main categories, namely opinions, attitudes and motives, beliefs and per- ceptions, behavior, facts and attributes, and knowledge (Silalahi, 2006).

The type of data used in this analysis is non-metric or qualitative primary data (data not in the form of numbers), which may be in the form of attributes, features, or particular characteristics that imply or characterize the subject (Sugiyono, 2011). Where the primary data in this study are data obtained directly at the research location or data derived through an interview and observation process. 
Techniques for collecting data are the most important phase of research, since the main objective of research is to collect data that meets the data requirements specified:

First, interview, in-depth interviews are one of the strengths of non-mainstream research (Basuki, 2016). The types of meetings used in this study are semistructured interviews and closed meetings. To guarantee the accuracy of the interview results, the researcher uses a voice recording device, audio, and or video in the interview process and then transcribed for checking the validity and reliability. Nevertheless, the conditions in the field that researchers follow are often different from the criteria predicted by researchers, so researchers must be innovative and imaginative when dealing with these conditions (Basuki, 2016).

Second, observation, data collection by view means that the researcher makes observations on the research site; in this case, the researcher must stay within the research site. The length of the representation shall not be constrained by time, tailored to the needs of the researcher. Inspection may be conducted directly; evaluation or assessment by the researcher is not prominent or secret (Basuki, 2016).

Third, triangulation model, in data collection techniques, triangulation is characterized as a mixture or combination of the different methods used to investigate interconnected phenomena from variety of perspectives and experiences (Denzin, 2007). Meanwhile, according to (Basuki, 2016), triangulation is the use of diverse data sources that are used to check and test the validity and reliability ("validity and reliability"), as well as being used as a data analysis tool. In this analysis, three models of triangulation were used, namely:

Data Triangulation, is the triangulation of sources and data forms obtained by researchers (Basuki, 2016). The triangulation of these data is carried out by comparing and testing the degree of trust of the information, among other things (1) comparing one observation data with another observation and (2) i am comparing the results of interviews with someone with others.

If one observation of the same thing is consistent compared to other comments, the results of interviews with one informant are steady compared to other informants; then, it can be said that the data collected is valid or valid (Basuki, 2016).

Triangulation researchers (Investigator triangulation), is an attempt to see the "objectivity and subjectivity" of researchers in conducting research (Basuki, 2016). This type of triangulation is done to test the honesty, subjectivity, and objectivity of researchers, using (1) ask for help from other researchers to re-direct observation, reinterview, and record the same data in the field. (2) i am comparing the results collected by someone with a different perspective with the results of other people's views.

Consistency is again used as a 'measuring device' for valid (valid) data collected by various researchers / observers (Basuki, 2016).

Methods of triangulation, is achieved by comparing different types of data and the way data are obtained (Basuki, 2016). This type of triangulation is used to "test" the reliability of the data collection methods, including (1) check whether the data/ information obtained from the interview is consistent with observation, and vice versa. (2) check whether the results of interviews and observations are consistent.

If the data produced by the two methods are consistent, it can be said that the data collection method is reliable (Basuki, 2016).

Data analysis is the approach used to organize and arrange data into theories and simple explanation units so that patterns and working ideas can be established, as indicated by the data. The type of research used in this study is a descriptive analysis, after which the data collected are processed and then analyzed by providing an inter- 
pretation of the above definition (Moleong, 2014).

\section{Interactive Model}

The method of analysis used for this research is an interactive model. Furthermore, Miles et al. (2014) suggests that the qualitative data analysis tasks are carried out interactively and continually before completion, so that the data is already saturated. The interactive study of the model is carried out through three operations, namely (1) Data Reduction, is content reduction means summarizing, selecting the primary points, concentrating on the basics. Decreasing data will therefore give a better image and make it easier for researchers to gather additional data (Sugiyono, 2011). (2) The next move is to show the data after the data has been that is Data Display. In qualitative research, this data can be presented in the form of charts, graphs and the like. When conducting such data, the data is structured in such a way that it is more easily understood (Sugiyono, 2011). (3) The third phase in the data of qualitative analysis, according to Miles \& Huberman, is the drawing of conclusions and checking is Conclusion Drawing / Verification. The initial findings reported are still provisional and will alter if there is no sufficient evidence to promote the next phase in data collection. Furthermore, if the results reported at an early stage are accompanied by reliable and consistent evidence when the researcher returns to the field to collect data, then the findings presented are plausible conclusions.

Therefore, the conclusions to be drawn in qualitative research may be capable of respond to the fulfillment of the problem that has been developed from the outset, But maybe not because of it has been mentioned that the problems in qualitative research are still transient and will grow after a field study.

The reason for choosing data analysis techniques using an interactive model is because the model will facilitate researchers.
The data that has been obtained in the field will be presented in a research report by providing analysis before the final step is to conclude.

\section{RESULT AND DISCUSSION}

\section{Results}

North Kalimantan is an Indonesian province situated in the northern part of the island of Kalimantan, which borders directly with neighboring countries, namely the states of Sabah and Sarawak, East Malaysia. The boundary of the land is approximately 1,308 $\mathrm{km}$ from the boundary between the Province of Kalimantan and the State of Malaysia.

In the previous chapter, Micro, Small and Medium-size Enterprises (MSMEs) are profitable companies owned by individuals or companies that have complied with the requirements. The time of the researcher's study and interview was between May and August 2019.

Informant. The selection of informants on their own should be made objectively (not randomly). In other words, if a study no longer needs information (the data obtained is deemed sufficient), then the researcher no longer needs to proceed by searching for information or other informants (new informants). This means that the number of informants can be minimal, but it can also be very high. It depends on choosing the informant itself, the diversity of the phenomenon under.

Study (subject matter of research). So what is important in qualitative research is the complete acquisition of information, not the amount of data. There are, therefore, three stages that can be made in the selection of informants. (1) collection of initial informants, whether informants (to be interviewed), (2) range of additional informants, with a view to expanding information and tracking all possible information, (3) stopping the selection of other informants should new data no longer appear (Subadi, 2006). 
In the following, the researchers present the examined informant, namely the SMEs in Tarakan City, in the form of a table, shown in Table 2, Table 3 and Table 4.

Observer 1 and Observer 2 tested the validity (validity) of observations of 15 informants of SMEs in Tarakan City. Based on the validity test, all views of 15 informants conducted by two researchers showed consistent (valid) results.

Interviewer 1 and interviewer 2 test the validity (validity) of interviews with 15 informants of SMEs in Tarakan City. Based on the validity test, all conversations with 15 informants conducted by two researchers showed consistent (valid) results.

The results of observations and interviews regarding the reliability test (reliability) of 15 informants SMEs perpetrators in the City of Tarakan. Based on the reliability test, all informants conducted by two researchers showed reliable results in Table 3.

After data reduction, there were only two informants from SMEs in Tarakan City (informants $\mathrm{N}$ and $\mathrm{O}$ ) who used Financial technology for funding purposes in terms of working capital. Informant $\mathrm{N}$ borrowed venture capital on Wall Flash, and informant $\mathrm{O}$ acquired venture capital on Mega Express. Wall Flash and Mega Express are androidbased applications that are not registered and do not have a business license at OJK. The data shown in Table 6.

From the results of data reduction where there are only two informants $(\mathrm{N}$ and $\mathrm{O})$, it can be concluded temporarily that only a small number of SMEs actors in Tarakan City are utilizing Financial technology for funding purposes, especially crowdfunding which is considered quite effective in overcoming capital problems. The data presentation in Table 7.

Conclusion Drawing. Furthermore, the results of verification between the frame of mind or the formulation of the problem with the initial conclusion produced a verified conclusion that a small number of SMEs actors in Tarakan City made use of Financial technology by utilizing Financial technology for funding purposes and utilizing crowdfunding for working capital. The conclusion in Table 8.

Table 2. Research Informant Data

\begin{tabular}{cccl}
\hline No. & Infor. & $\mathrm{M} / \mathrm{F}$ & Business Type \\
\hline 1. & $\mathrm{A}$ & $\mathrm{F}$ & Various Snacks \\
2. & $\mathrm{B}$ & $\mathrm{F}$ & Processed Foods from Seaweed \\
3. & $\mathrm{C}$ & $\mathrm{M}$ & Various Kinds of Chips \\
4. & $\mathrm{D}$ & $\mathrm{F}$ & Spicy Flavor Chips \\
5. & $\mathrm{E}$ & $\mathrm{M}$ & Various forms of flavor and taste \\
6. & $\mathrm{~F}$ & $\mathrm{~F}$ & Milkfish Cheese Stick \\
7. & $\mathrm{G}$ & $\mathrm{F}$ & Processed Fishery Products \\
8. & $\mathrm{H}$ & $\mathrm{F}$ & Paper Chips \\
9. & $\mathrm{I}$ & $\mathrm{F}$ & Apparel and Clothing \\
10. & $\mathrm{J}$ & $\mathrm{F}$ & Various Flavors of Grass Jelly \\
11. & $\mathrm{K}$ & $\mathrm{F}$ & Screen Printing and Packaging \\
12. & $\mathrm{L}$ & $\mathrm{F}$ & Caramelized Banana Chips \\
13. & $\mathrm{M}$ & $\mathrm{F}$ & Cassava Cake Tela \\
14. & $\mathrm{N}$ & $\mathrm{M}$ & Carving Sketch in Leaf Services \\
15. & $\mathrm{O}$ & $\mathrm{F}$ & Various snacks creation \\
\hline
\end{tabular}


Table 3. Observation Data Validity Test Table Results

\begin{tabular}{|c|c|c|c|c|}
\hline \multirow[t]{2}{*}{ No } & \multirow{2}{*}{ Informant } & \multicolumn{2}{|c|}{ Observer } & \multirow{2}{*}{ Valid } \\
\hline & & 1 & 2 & \\
\hline 1. & $\begin{array}{l}\text { A, B, C, D, } \\
\text { E, F, G, H, } \\
\text { I, J, K, L, } \\
\text { M }\end{array}$ & $\begin{array}{l}\text { Informants do not know about } \\
\text { Financial technology. } \\
\text { Informants do not use Financial } \\
\text { technology. } \\
\text { Informants do not use crowd- } \\
\text { funding facilities. } \\
\text { Crowdfunding is not sufficient } \\
\text { enough to overcome the problem } \\
\text { of business capital informants. }\end{array}$ & $\begin{array}{l}\text { Informants do not know about } \\
\text { Finan-cial technology. } \\
\text { Informants do not use Financial } \\
\text { tech-nology. } \\
\text { Informants do not use } \\
\text { crowdfunding facilities. } \\
\text { Crowdfunding is not sufficient } \\
\text { enough to overcome the problem of } \\
\text { business capital informants. }\end{array}$ & Valid \\
\hline 2. & $\mathrm{~N} \& \mathrm{O}$ & $\begin{array}{l}\text { Informants know about Financial } \\
\text { technology. } \\
\text { Informants utilize Financial } \\
\text { technology for funding purposes. } \\
\text { Informants use crowdfunding } \\
\text { facilities in Financial technology } \\
\text { for working capital. } \\
\text { Crowdfunding is quite effective in } \\
\text { overcoming the capital problems } \\
\text { of business informants. }\end{array}$ & $\begin{array}{l}\text { Informants know about Financial } \\
\text { tech-nology. } \\
\text { Informants utilize Financial tech- } \\
\text { nology for funding purposes. } \\
\text { Informants use crowdfunding } \\
\text { facilities in Financial technology } \\
\text { for working capital. } \\
\text { Crowdfunding is quite effective in } \\
\text { overcoming the capital problems of } \\
\text { business informants. }\end{array}$ & Valid \\
\hline
\end{tabular}

Source: adapted from Basuki (2016)

Table 4. Table of Interview Data Validity Test Results

\begin{tabular}{|c|c|c|c|c|c|c|c|c|}
\hline \multirow{3}{*}{ No. } & \multirow{3}{*}{ In. } & \multicolumn{6}{|c|}{ Interviewer } & \multirow{3}{*}{ Valid } \\
\hline & & \multicolumn{3}{|c|}{1} & \multicolumn{3}{|c|}{2} & \\
\hline & & Knowledge & The benefits & Effectiveness & Knowledge & The benefits & Effectiveness & \\
\hline 1. & $\begin{array}{l}\text { A, } \\
\text { B, } \\
\text { D, } \\
\text { E, } \\
\text { F }\end{array}$ & $\begin{array}{l}\text { Informants } \\
\text { do not know } \\
\text { about } \\
\text { Financial } \\
\text { technology }\end{array}$ & $\begin{array}{l}\text { Informants do } \\
\text { not utilize } \\
\text { Financial } \\
\text { technology } \\
\text { and } \\
\text { crowdfunding } \\
\text { facilities }\end{array}$ & $\begin{array}{l}\text { Crowdfunding } \\
\text { is not sufficient } \\
\text { enough to } \\
\text { overcome the } \\
\text { problem of } \\
\text { business capital } \\
\text { informants }\end{array}$ & $\begin{array}{l}\text { Informants } \\
\text { know about } \\
\text { Financial } \\
\text { technology }\end{array}$ & $\begin{array}{l}\text { Informants } \\
\text { utilize } \\
\text { Financial } \\
\text { technology for } \\
\text { funding } \\
\text { purposes }\end{array}$ & $\begin{array}{l}\text { Crowdfunding } \\
\text { is quite } \\
\text { effective in } \\
\text { overcoming } \\
\text { the capital } \\
\text { problems of } \\
\text { business } \\
\text { informants }\end{array}$ & Valid \\
\hline 2. & $\begin{array}{l}\mathrm{C}, \\
\mathrm{G}, \\
\mathrm{H}, \\
\mathrm{I}, \mathrm{J} \\
\mathrm{K}, \\
\mathrm{L}, \\
\mathrm{M}\end{array}$ & $\begin{array}{l}\text { Informants } \\
\text { do not know } \\
\text { about } \\
\text { Financial } \\
\text { technology }\end{array}$ & $\begin{array}{l}\text { Informants do } \\
\text { not utilize } \\
\text { Financial } \\
\text { technology } \\
\text { and } \\
\text { crowdfunding } \\
\text { facilities }\end{array}$ & $\begin{array}{l}\text { Crowdfunding } \\
\text { is not sufficient } \\
\text { enough to } \\
\text { overcome the } \\
\text { problem of } \\
\text { business capital } \\
\text { informants }\end{array}$ & $\begin{array}{l}\text { Informants } \\
\text { do not know } \\
\text { about } \\
\text { Financial } \\
\text { technology }\end{array}$ & $\begin{array}{l}\text { Informants do } \\
\text { not use } \\
\text { Financial } \\
\text { technology } \\
\text { and } \\
\text { crowdfunding } \\
\text { facilities }\end{array}$ & $\begin{array}{l}\text { Crowdfunding } \\
\text { is } \\
\text { sufficient not } \\
\text { enough to } \\
\text { overcome the } \\
\text { problem of } \\
\text { business } \\
\text { capital } \\
\text { informants }\end{array}$ & Valid \\
\hline 3. & $\begin{array}{l}\mathrm{N} \\
\& \\
\mathrm{O}\end{array}$ & $\begin{array}{l}\text { Informants } \\
\text { know about } \\
\text { Financial } \\
\text { technology }\end{array}$ & $\begin{array}{l}\text { Informants } \\
\text { utilize } \\
\text { Financial } \\
\text { technology for } \\
\text { funding } \\
\text { purposes }\end{array}$ & $\begin{array}{l}\text { Crowdfunding } \\
\text { is quite effective } \\
\text { in overcoming } \\
\text { the capital } \\
\text { problems of } \\
\text { business } \\
\text { informants }\end{array}$ & $\begin{array}{l}\text { Informants } \\
\text { know about } \\
\text { Financial } \\
\text { technology }\end{array}$ & $\begin{array}{l}\text { Informants } \\
\text { utilize } \\
\text { Financial } \\
\text { technology for } \\
\text { funding } \\
\text { purposes }\end{array}$ & $\begin{array}{l}\text { Crowdfunding } \\
\text { is quite } \\
\text { effective in } \\
\text { overcoming } \\
\text { the capital } \\
\text { problems of } \\
\text { business } \\
\text { informants }\end{array}$ & Valid \\
\hline
\end{tabular}

Source: adapted from Basuki (2016) 
Table 5. Data Reliability Test Results Table

\begin{tabular}{ccccc}
\hline No. & Informant & $\begin{array}{c}\text { Observation } \\
\text { Validity }\end{array}$ & $\begin{array}{c}\text { The validity of } \\
\text { the Interview }\end{array}$ & Reliability \\
\hline 1. & A & Valid & Valid & Reliable \\
2. & B & Valid & Valid & Reliable \\
3. & C & Valid & Valid & Reliable \\
4. & D & Valid & Valid & Reliable \\
5. & E & Valid & Valid & Reliable \\
6. & F & Valid & Valid & Reliable \\
7. & G & Valid & Valid & Reliable \\
8. & H & Valid & Valid & Reliable \\
9. & I & Valid & Valid & Reliable \\
10. & J & Valid & Valid & Reliable \\
11. & K & Valid & Valid & Reliable \\
12. & L & Valid & Valid & Reliable \\
13. & M & Valid & Valid & Reliable \\
14. & N & Valid & Valid & Reliable \\
15. & O & Valid & Valid & Reliable \\
\hline
\end{tabular}

Source: adapted from Basuki (2016)

Table 6. Data Reduction

\begin{tabular}{|c|c|c|c|c|c|c|}
\hline No & Infor. & \multicolumn{2}{|c|}{ Financial technology } & \multicolumn{2}{|c|}{ Crowdfunding } & Post. \\
\hline & & Know. & Utiliz. & Utiliz. & ffectiv. & \\
\hline 1. & $\mathrm{~N}$ & $\begin{array}{l}\text { Informants } \\
\text { know about } \\
\text { Financial } \\
\text { technology }\end{array}$ & $\begin{array}{l}\text { Informants } \\
\text { utilize Financial } \\
\text { technology for } \\
\text { funding } \\
\text { purposes }\end{array}$ & $\begin{array}{l}\text { The informant } \\
\text { borrows } \\
\text { venture capital } \\
\text { on Wall Flash }\end{array}$ & $\begin{array}{l}\text { Crowdfunding is } \\
\text { quite effective in } \\
\text { overcoming the } \\
\text { wealth of business } \\
\text { informants }\end{array}$ & $\begin{array}{l}\text { Informant } \\
\text { borrow the } \\
\text { money at } \\
\text { Wall Flash }\end{array}$ \\
\hline 2. & $\mathrm{O}$ & $\begin{array}{l}\text { Informants } \\
\text { know about } \\
\text { Financial } \\
\text { technology }\end{array}$ & $\begin{array}{l}\text { Informants } \\
\text { utilize Financial } \\
\text { technology for } \\
\text { funding } \\
\text { purposes }\end{array}$ & $\begin{array}{l}\text { The informant } \\
\text { borrows } \\
\text { venture capital } \\
\text { at Mega } \\
\text { Express }\end{array}$ & $\begin{array}{l}\text { Crowdfunding is } \\
\text { quite effective in } \\
\text { overcoming the } \\
\text { wealth of business } \\
\text { informants }\end{array}$ & $\begin{array}{l}\text { Informant } \\
\text { borrow the } \\
\text { money at } \\
\text { Mega } \\
\text { Express }\end{array}$ \\
\hline
\end{tabular}

Source: adapted from Sugiyono (2011)

Table 7. Data Presentation

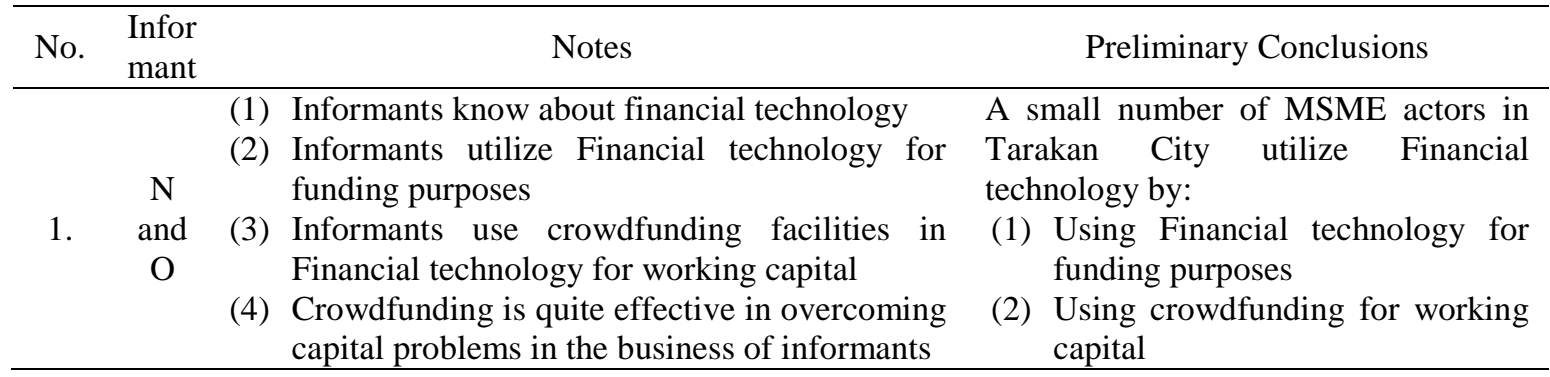

Source: adapted from Sugiyono (2011)

Table 8. Withdrawal of Conclusions

\begin{tabular}{|c|c|c|}
\hline $\begin{array}{l}\text { Conclusions } \\
\text { (1) }\end{array}$ & $\begin{array}{l}\text { Framework of } \\
\text { thinking } \\
\text { (2) }\end{array}$ & $\begin{array}{l}\text { Conclusion Verified } \\
\text { (3) }\end{array}$ \\
\hline $\begin{array}{l}\text { A small number of SMEs actors in } \\
\text { Tarakan City utilize Financial technology } \\
\text { by: } \\
\text { (1) Utilizing Financial technology for } \\
\text { funding purposes } \\
\text { (2) Utilizing crowdfunding for working } \\
\text { capital }\end{array}$ & $\begin{array}{l}\text { How SMEs in } \\
\text { Tarakan City make } \\
\text { use of crowdfunding- } \\
\text { based Financial } \\
\text { technology }\end{array}$ & $\begin{array}{l}\text { A small number of SMEs actors in } \\
\text { Tarakan City utilize Financial } \\
\text { technology by: } \\
\text { (1) Utilizing Financial technology } \\
\text { for funding purposes } \\
\text { (2) Utilizing crowdfunding for } \\
\text { working capital }\end{array}$ \\
\hline
\end{tabular}




\section{Discussion}

Using Financial technology for Funding Purposes. Financial technology is a new innovation in financial services that is expected to bring financial transactions that are more practical and secure, this financial transaction process includes payment, borrowing money, transferring, or buying and selling shares (Carney, 2016). The development of Financial technology has now become the latest study in Indonesia. The presence of Financial technology has a purpose so that people who do not yet have financial access in banking can be touched by the presence of Financial technology. Financial technology will be the most potential digital business because any business will need Financial technology (Hartojo, 2017).

Based on the finding of research carried out against 15 informants on small and medium-sized enterprises in the City of Tarakan, only a small proportion of those using financial technology have been identified in the City of Tarakan. This is due to the lack of level of knowledge that frightens MSMEs to take advantage of Financial technology, whereas Financial technology by a small number of MSMEs who do not yet have financial access in banking (Hartojo, 2017) has been used for funding purposes, especially crowdfunding services to meet the needs of working capital because proven financial transactions can be done more practically and safely (Carney, 2016).

The results also reinforce the finding of other studies, which conclude that the presence of Financial technology companies also contributed to the funding of venture capital in MSMEs (Muzdalifa et al., 2018).

Utilizing Crowdfunding for Working Capital. While the results of subsequent studies also concluded only a small proportion of SMEs in the City of
Tarakan to meet the needs of working capital. This is due to the lack of knowledge of SMEs about Financial technology, especially crowdfunding, where so far, crowdfunding is better known as a funding facility (funding) for social interests (Kurniawan, 2015). Whereas with substantial social capital (Prihantono, 2016), crowdfunding can be a mediator between creditors and potential debtors in the future.

Furthermore, the results also reinforce finding of other researchs, which conclude that crowdfunding is present in answering the problem of venture capital for SMEs to be able to develop their business with working capital.

\section{CONCLUSIONS}

On the basis of research on the use of crowdfunding-based financial technology by small and medium-sized enterprises in Tarakan City, it can be concluded (1) Based on 15 informants examined, there were only two informants who knew about Financial technology, and among others did not understand Financial technology. (2) Only a limited number of small and medium-sized businesses in Tarakan City are able to use crowdfunding-based financial technology for financing needs and use crowdfunding for working capital. And (3) Small and medium-sized businesses (SMEs) in the City of Tarakan have an excellent opportunity to use crowdfunding-based financial technology for financing needs and to use crowdfunding for working capital.

Number of ideas are expected to be useful for future business interests in enhancing financial technology empowerment for SMEs in Tarakan City: strong synergy and cooperation in developing a financial technology system to improve digital economic policy for future SMEs, particularly SMEs in the City of Tarakan. This idea is to improve literacy or financial knowledge so that people can learn more about business technologies so 
that people are more successful in their regional economy.

Beside that, SMEs should utilize financial technology for overcoming SMEs financial problem. In this case is utilize crowdfunding for overcoming SMEs capital problem. Through crowdfunding SMEs will easily obtain capital that can be used to develop the company.

This study was conducted using qualitative descriptive methods and using primary data obtained through observation and interview structures. The study only used 15 informants from the SMEs of Tarakan City. Further research is expected to use more research samples and use quantitative methods for analysis tools, so the results can be generalized for Kalimantan Island or Indonesia.

\section{REFERENCES}

Ardan Adhi, C. (2016). UMKM Serap 57,9 Juta Tenaga Kerja.

Arifin, S. R., \& Wisudanto, W. (2017). Crowdfunding Sebagai Alternatif Pembiayaan Pembangunan Infrastruktur. Simposium II UNIID 2017, 2(1), 309-314.

Bachir, S. (2019). Revolusi Industri 4.0 Peluang Besar Bagi UMKM.

Basuki. (2016). Metode Penelitian Akuntansi dan Manajemen, Berbasis Studi Kasus.

Carney, M. (2016). Enabling the FinTech transformation: Revolution, Restoration, or reformation? Speech by the Governor. Lord Mayor's Banquet for Bankers and Merchants of the City of London at the Mansion House. Bank of England.

Denzin, N. K. (2007). Triangulation. The Blackwell Encyclopedia of Sociology.
Freedman, D. M., \& Nutting, M. R. (2015). A brief history of crowdfunding including rewards, donation, debt, and equity platforms in the USA. Retrieved, 30, 2016.

Hartojo, W. (2017). Financial Technology Diprediksi jadi Bisnis Paling Potensial di Indonesia.

Herdiawan, J. (2018). Ketahui Jenis Fintech dan Dampaknya Bagi Financial Anda.

Hidayat, E. (2016). Kadin: UMKM Berperan Penting Perangi Kemiskinan.

Irwanto, J. (2013). Sumber Pendanaan Crowdfunding: Indiegogo \& Kickstarter.

Kurniawan, I. (2015). Crowdfunding Jadi Alternatif Pendanaan UMKM.

Massolution. (2015). Massolution Report Released: Crowdfunding Market Grows 167\% in 2014, Crowdfunding Platforms Raise \$16.2 Billion.

Miles, M. B., Huberman, A. M., \& Saldaña, J. (2014). Qualitative data analysis: A methods sourcebook. 3rd. Ed: Thousand Oaks, CA: Sage.

Moleong, J. (2014). Metodologi Penelitian Kualitatif. In PT. Remaja Rosdakarya.

Muzdalifa, I., Rahma, I. A., \& Novalia, B. G. (2018). Peran Fintech Dalam Meningkatkan Keuangan Inklusif Pada UMKM Di Indonesia (Pendekatan Keuangan Syariah). Jurnal Masharif Al-Syariah: Jurnal Ekonomi Dan Perbankan Syariah, 3(1).

Nisaputra, R. (2016). Kadin: UMKM Berperan Penting Perangi Kemiskinan.

Otoritas Jasa Keuangan. (2019). Penyelenggara Fintech Terdaftar dan Berizin di OJK per 31 Mei 2019. 
Prihantono, G. (2016). Pengaruh Modal Sosial dan Sosial Ekonomi Terhadap Nilai Valuasi Ekonomi Air Bersih Di Kota Surabaya. Jurnal Ekonomi Dan Bisnis Airlangga (JEBA)| Journal of Economics and Business Airlangga, 26(1), 12-23.

Sembiring, M. (2013). Baru 30\% UMKM yang mengakses perbankan.

Setyo, B. (2019). UMKM Bisa Ambil Untung dari Kehadiran Fintech.

Silalahi, U. (2006). Metode penelitian sosial. Unpar press.

Subadi, T. (2006). Metode Penelitian Kualitatif. Muhammadiyah University Press.

Sugiyono, P. (2011). Metodologi penelitian kuantitatif kualitatif dan $R \& D$. Alpabeta, Bandung.

Suwarsono. (2017). Produk UMKM Terkendala Pasar dan Kemasan.

Valanpienơa, L., \& Jegelevipinjtob, S. (2014). Crowdfunding for creating value: stakeholder approach. Procedia-Social and Behavioral Sciences, 156, 599-604.

Vulkan, N., Åstebro, T., \& Sierra, M. F. (2016). Equity crowdfunding: A new phenomena. Journal of Business Venturing Insights, 5, 37-49. 